\title{
Analysis of factor affecting Islamic commercial bank financing for the agricultural sector in Indonesia
}

\author{
Satrio Arif Wicaksono ${ }^{1 *}$, Yeny Fitriyani ${ }^{2}$ \\ ${ }^{1}$ Faculty of Business and Economics, Universitas Islam Indonesia, Yogyakarta, \\ Indonesia \\ 2 Sekolah Tinggi Agama Islam Al Husein, Magelang, Indonesia \\ ${ }^{*}$ Corresponding author: satrioarifwicaksono1@gmail.com
}

\begin{abstract}
Purpose: This study aims to analyse the factors that influence Islamic commercial bank financing for the agricultural sector in Indonesia from January 2015 to April 2019.
\end{abstract}

Methodology: Variables used in this study are Agricultural Financing, DPK, NPF, Inflation, Exchange Rates, SBIS, and IPI. The method used in this research is the VAR/VECM method with Impulse Response Function (IRF) analysis and Forecast Error Variance Decomposition (FEVD).

Findings: The results show that the variables that significantly influence agricultural financing in the long-term are DPK, Exchange Rate, and IPI. Taking a closer detail, IPI variable has a positive effect, while the DPK and Exchange Rate have a negative effect on agricultural financing. Then NPF, inflation, and SBIS have no effect on agricultural financing in the short and long-term. Based on the results of FEVD, the variable that has the greatest contribution to agricultural financing is DPK compared to Exchange Rate and IPI.

Practical applications: Islamic bank directors prioritize efforts to increase funding in order to encourage an increase in the portion of financing in the agricultural sector.

Originality: This study examines the effect of financial and macroeconomic performance on mudharabah financing in the short and long term in Indonesia.

Keywords: Agricultural financing, Islamic commercial bank, deposit fund, exchange rate, industrial production index.

Cite this article:

Wicaksono, S. A. \& Fitriyani, Y. (2020). Analysis of factor affecting Islamic commercial bank financing for the agricultural sector in Indonesia. Asian Journal of Islamic Management, 2(2), 123-137. https://doi.org/10.1108/AJIM.vol2.iss2.art5
Article History

Received, 02 November 2020

Revised 1, 20 November 2020

Revised 2, 2 December 2020

Accepted, 5 December 2020

\section{Introduction}

The agricultural sector is a leading and strategic sector to increase national growth in Indonesia. The agricultural sector also gives an important contribution to national development. One of the problems in the agricultural sector is the limited access to finance causing a lot of agricultural land being not utilized optimally. The agricultural sector is known as a risky business sector, so the interest of financial institutions to finance business in this sector is relatively low (Beik \& Aprianti, 2013). 
Several studies have shown that the proportion of banking financing for the agricultural sector is still far below the financing of the industrial, trade, goods, services, and other sectors that are gaining profits quickly (Tsabita, 2014). One of the reasons for the low allocation of financing in the agricultural sector is the absence of special treatment and proper financing schemes from the financing institutions for the agricultural sector. So far, policies for agricultural financing have been integrated with financing in the real sector, so that agricultural financing is not competitive (Syahri \& Harjito 2020; Sudarsono et al., 2020). To further ensure the availability of business capital for agricultural business actors, it is necessary to look for alternative financing models that are in accordance with the characteristics of businesses in the agricultural sector, namely the Islamic financing model (Septindo et al., 2016). This model provides more justice and principles to the profit-sharing system, not the interest system which often results in bankruptcy for farmers and agricultural business actors.

Islamic Commercial Bank is one of the solutions developed and expected to help in providing financing facilities for the agricultural sector by offering capital with a profit-sharing system and not charging interest for their customers.

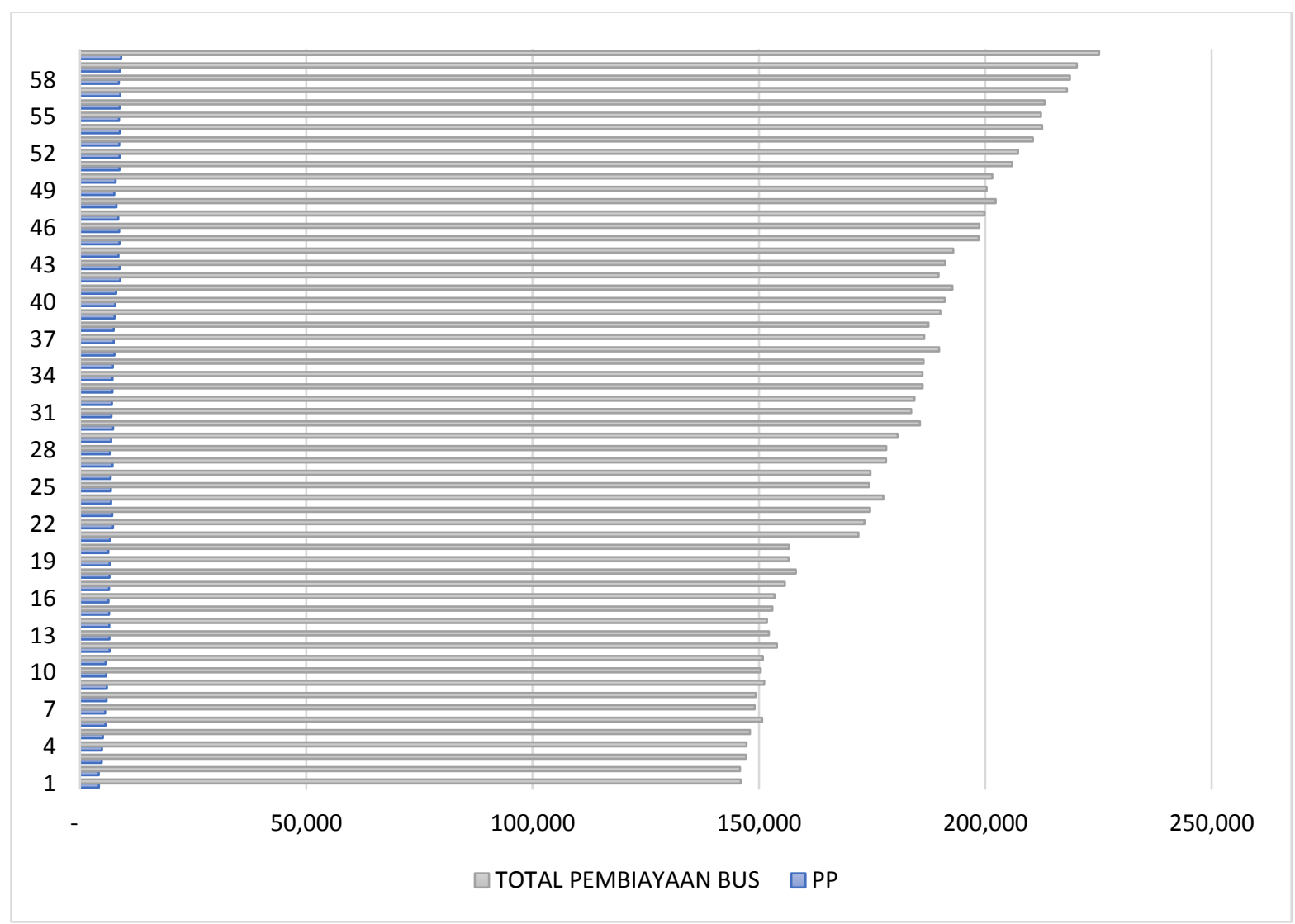

Source: Islamic Banking Statistics (processed)

Figure 1. Comparison of Agricultural Financing towards

Total Financing of Islamic Commercial Bank

In Figure 1, it can be seen that the amount of financing value for Islamic Commercial Banks in Indonesia has fluctuated and generally increased in the period of January 2015 to April 2019. In January 2015, the value of financing was 4,187 and increased to 9,108 in December 2019. However, the amount of agricultural financing to the total financing of Islamic Commercial Banks is still relatively small compared to other financing in January 2015 and April 2019 at 3\%and 4\% respectively. It can be seen that the period from January 2015 to April 2019 only 
increased by $1 \%$. This may be influenced by several factors which are monetary policy instruments, macroeconomic indicators, and the performance of Islamic Commercial Banks.

This study aims to determine how the influence of the abovementioned factors and determine the response or shocks that occur in the long-term with the IRF analysis that affects agricultural financing and to find out how much the contribution of related variables to agricultural financing with FEVD analysis. Based on the previous research, the results obtained are varied and the interesting part of this study is adding the IPI variable as a macroeconomic indicator and the exchange rate variable as an instrument of Central Bank of Indonesia. Therefore, this research analyses the factors that affect the financing of Islamic Commercial Banks for the agricultural sector in Indonesia from January 2015 to April 2019. The related previous studies include Beik and Aprianti (2013), Mughits and Wulandari (2016), Septindo et al. (2016), Maulana and Iskandar (2018), Kusumawati (2013), Purwanto (2018), Ashari (2009), Ashari and Saptana (2016), Saragih (2017), Sudarsono (2017), Rahmah and Armina (2020), Majid and Ulina (2020), Jaya et al. (2015), Veratama (2013), and Nasution (2016).

This research is limited only to financing in the agricultural sector at Islamic Commercial Banks (BUS), without including data from the Islamic Business Unit (UUS) or Islamic Rural Bank (BPRS). The data used are monthly data for the period of January 2015 to April 2019. The factors used in this study are limited to several variables describing banking performance are agricultural financing (PP), deposit funds (DPK), and Non-Performing Financing (NPF). The variables that describe the monetary instruments are Bank Indonesia Sharia Certificate (SBIS) and Exchange Rate (KURS). The variables that describe the macroeconomic indicators are inflation and Industrial Production Index (IPI).

\section{Literature Review}

\section{Islamic Banking}

Islamic Banking is all aspects concerning Islamic Banks and Islamic Business Units, including institutions, business activities, methods and processes in carrying out their business activities. Islamic Commercial Bank is a Islamic Bank in which its activities provide services in payment traffic. Islamic Bank is a bank that operates without relying on interest. Islamic Bank or commonly known as Bank without interest, is a financial/banking institution whose operations and products are developed based on Al-Qur'an and Hadith. In other words, Islamic Bank is a financial institution whose main business is providing financing and other services in payment traffic and circulation of money complying with the principles of Islamic law (Muhammad, 2005). The main characteristic of Islamic banking is the absence of interest as a representation of the prohibited usury (Septindo et al., 2016). These characteristics make Islamic banking superior in several ways, including its operational system.

\section{Islamic Financing}

As stated in Law No. 21 of 2008 article 19 paragraph 1. The functions and activities of Islamic Commercial Banks are collecting and channeling funds which are referred to as financing. The existence of Islamic Commercial Bank is expected to contribute to the economic growth of the community through financing issued by Islamic Commercial Banks. Through this financing, Islamic Commercial Banks can establish partnership relationships with customers, so that the relationship between Islamic Commercial Banks and customers is no longer a creditor and debtor but becomes a partnership and establishes a cooperative relationship (Mughits \& Wulandari, 2016).

\section{Deposit funds (DPK)}

According to Law No. 21 of 2008 concerning Islamic banking (Article 1) states that Deposits are funds entrusted by the Customer to a Islamic Commercial Bank and/or Islamic Business Unit 
based on contract of wadi'ah or other contracts that do not conflict with Islamic Principles in the form of demand deposits, Savings, or others. Public funds that are collected and stored in banks are the largest source of funds that banks rely on, consisting of 3 types namely demand deposits, deposits and savings (Jaya et al., 2015). The public believes that the existence of a bank will manage its financial problems as well as possible condition expected by all banks.

\section{Non-Performing Financing (NPF)}

As an indicator showing losses due to financing risk, this is reflected in the NPF. NonPerforming Financing (NPF) is the ratio between problematic financing and total financing disbursed by Islamic Commercial Banks (Rahmah \& Armina, 2020). Based on the criteria set by Central Bank of Indonesia, the categories included in the NPF are substandard, doubtful, and non-performing financing (Rahman \& Fatmawati, 2020; Permataningayu, \& Mahdaria, 2020). Cost control has a relationship to the performance of banking institutions, so that the tighter the financing policies implemented by the bank (the more the NPF level is pressed) will cause the level of demand for financing by the public to fall (Syafi'i, 2001).

\section{Inflation (INF)}

Inflation is a condition of price increases in general and occurs continuously within a certain period of time. An increase in the price of one or two goods alone cannot be called inflation unless it extends (or results in price increases) to other goods. To measure inflation, an index number is needed. The indicator that is often used to measure the inflation rate is the Consumer Price Index CPI). Changes in the CPI from time to time indicate price movements of packages of goods and services consumed by the public (Suseno \& Astiyah, 2010). The determination of goods and services in the CPI basket is carried out on the basis of the Cost of Living Survey (SBH) conducted by the Central Statistics Agency (BPS).

\section{Exchange Rate (KURS)}

The exchange rate is the price of one unit of foreign currency in domestic currency or it can also be said that the price of domestic currency against foreign currency. For example, the exchange rate (NT) of Rupiah against US Dollars (USD) is the price of one US dollar (USD) in Rupiah (IDR), or it can also be interpreted as the price of one Rupiah to one USD (Suseno \& Simorangkir, 2004). Economic conditions affect banking activities. The indicator that is often used to regulate economic stability is the exchange rate. The fluctuating impact of the exchange rate resulted in the tendency of people to want to have foreign currency so they made withdrawals from banks which resulted in the bank experiencing difficulties in channelling their funds (Sudarsono, 2017). Further, an increase in the exchange rate can cause the price of raw materials to be more expensive because the value of foreign currencies will increase while the value of the domestic currency will depreciate and vice versa.

\section{Bank Indonesia Sharia Certificate (SBIS)}

As stated in the Bank Indonesia regulation concerning SBIS No. 10 article 1 paragraph 4, Bank Indonesia Sharia Certificates, hereinafter referred to as SBIS, are short-term securities based on Islamic Principles in rupiah currency issued by Central Bank of Indonesia (Bank Indonesia, 2017). Central Bank of Indonesia determines and rewards SBIS issued at the maturity of the SBIS through an auction mechanism (Beik \& Aprianti, 2013; Septindo et al., 2016)).

\section{Industrial Production Index (IPI)}

The Industrial Production Index (IPI) is a monthly economic indicator that measures real output in the manufacturing, mining, electricity, and gas industries, relative to the base year. According 
to the Central Statistics Agency, the Industrial Production Index (IPI) is used as the basis for calculating gross domestic product (GDP). IPI is an indicator that shows the business cycle in a country. When experiencing an increase in IPI, a country's business cycle experiences a period of expansion where company productivity is also increasing. This increase indicates that the economy is starting to grow better or is in a period of expansion, consistent with real business cycle theory (Masrizal et al., 2020). IPI measures changes in production volume that occur from various production sectors from time to time. IPI is the information used by investors to determine the company they will invest in, namely companies that have good performance and have long-term growth.

\section{Research Method}

This research ias a quantitative study using time series data. The data used is monthly secondary data from January 2015 to April 2019. Data is taken from various sources, namely, Bank Indonesia website, Islamic Banking Statistics (SPS), Central Statistics Agency (BPS), International Financial Statistics (IFS), and other data sources which support this research.

The method used in this research is the VAR / VECM method. The stationary data test is the first step in estimating the VAR / VECM model, this test is often called the unit root test by looking at the Augmented Dicky Fuller (ADF) value to see stationary and non-stationary data.

Furthermore, selecting the optimum lag. Determination of the amount of lag to be used in the VAR model can be decided based on the criterion of Akaike Information Criterion (AIC) and the Hannan-Quinn information criterion (HQ). The lag to be selected in this study is the model with the smallest AIC value. In this stage, the VAR model stability test is also carried out to test the stability of the VAR estimation that has been determined, a VAR condition stability check is carried out, namely in the form of a roots of characteristic polynomial. A VAR model is said to be stable if all of its roots have a modulus of less than 1.

Then the cointegration, the cointegration test means that there is a long-term equilibrium relationship. In the short-term and possible imbalance. Because of this imbalance, it is necessary to do evaluation with the error correction model using Johansen's Trace Statistics. The Granger Causality Test is conducted to see whether two variables have a causal relationship or not. In other words, does one variable have a significant causal relationship with other variables?

VAR / VECM estimation is used to see short-term and long-term relationships. Impulse Response Function (IRF) is to see how agricultural financing responds to shocks of other variables, and Variance Decomposition (FEVD) is to see how much other variables contribute to affecting agricultural financing. The results of data processing are processed using data processing applications, namely Eviews 10.

\section{Result and Discussion}

\section{Data Stationarity Test}

Table 1 describes the results of the stationarity test using the Augmented Dickey Fuller test (ADF) method with a critical value of 5 percent. The data stationarity test is carried out by looking at the probability value at the level and the first difference is said to be stationary if it is seen from the ADF value which is smaller than Critical Values and vice versa when viewed from the ADF value is greater than Critical Values, then the data is not stationary.

Based on the results of the ADF test at the level, all variables are not stationary except for INF and LNKURS. This can be seen from the ADF statistical value of all variables that is greater than the t-statistic value, except for INF and LNKURS which have ADF statistical values that are smaller than their t-statistical value. Meanwhile, based on the unit root test at the first difference level using the ADF test, it was found that all the variables were stationary at the first difference level. This can be seen from the ADF statistical value of all variables that is smaller than the $t-$ statistic value. 
Table 1. Stationarity Test Results in the Model

\begin{tabular}{lcccc}
\hline \multirow{2}{*}{ Variables } & \multicolumn{3}{c}{ Level } & First Difference \\
\cline { 2 - 5 } & ADF & t-statistic & ADF & t-statistic \\
& Value & Value $(5 \%)$ & Value & Value (5\%) \\
\hline LNPP & -1.845757 & -2.919952 & -6.638680 & -2.922449 \\
LNDPK & -0.582420 & -2.919952 & -8.437618 & -2.921175 \\
NPF & -1.220923 & -2.923780 & -3.201222 & -2.923780 \\
INF & -6.870577 & -2.922449 & -7.729302 & -2.926622 \\
LNKURS & -7.302104 & -2.919952 & -6.202116 & -2.929734 \\
SBIS & -1.311415 & -2.919952 & -5.781529 & -2.921175 \\
LNIPI & -1.860298 & -2.921175 & -11.94835 & -2.921175 \\
\hline
\end{tabular}

\section{Optimum Lag Test}

Table 2. Optimum Lag Test Result

\begin{tabular}{ccc}
\hline Lag & AIC & HQ \\
\hline 0 & -6.921458 & -6.817216 \\
1 & -6.607266 & -5.773329 \\
2 & -6.261544 & -4.697911 \\
3 & -6.187026 & -3.893698 \\
4 & -7.297978 & -4.274955 \\
5 & $-12.30660^{*}$ & $-8.553878^{*}$ \\
\hline
\end{tabular}

Based on Table 2, it can be seen that the optimum lag test results state that the optimal lag in this study is at lag 5 with the lowest value on the Akaike Information Criteria (AIC) and Hannan-Quinn Information Criteria (HQ) criteria. Therefore, the optimum lag length and the selected lag is lag 5 .

\section{Model Stability Test}

Table 3. Model Stability Test Result

\begin{tabular}{lc}
\hline Root & Modulus \\
\hline$-0.260914-0.646199 \mathrm{i}$ & 0.696886 \\
$-0.260914+0.646199 \mathrm{i}$ & 0.696886 \\
$0.188289-0.607996 \mathrm{i}$ & 0.636484 \\
$0.188289+0.607996 \mathrm{i}$ & 0.636484 \\
$-0.498344-0.355879 \mathrm{i}$ & 0.612370 \\
$-0.498344+0.355879 \mathrm{i}$ & 0.612370 \\
$0.591730-0.142678 \mathrm{i}$ & 0.608688 \\
$0.591730+0.142678 \mathrm{i}$ & 0.608688 \\
-0.532848 & 0.532848 \\
$-0.323224-0.406435 \mathrm{i}$ & 0.519291 \\
$-0.323224+0.406435 \mathrm{i}$ & 0.519291 \\
-0.473554 & 0.473554 \\
$0.074333-0.369434 \mathrm{i}$ & 0.376838 \\
$0.074333+0.369434 \mathrm{i}$ & 0.376838 \\
\hline
\end{tabular}

Based on the results of the VAR model stability test in Table 3, the modulus value is less than 1, it can be concluded that the VAR estimation used for the IRF and FEVD analysis is stable. 


\section{Cointegration Test}

Based on the cointegration test using Johansen's Trace Statistics, the number of co-integrated equations in the system will be obtained. The test was carried out by looking at the trace statistic value compared to the Critical Value which in this study was used at 5 percent. The equation is said to be co-integrated if the trace statistic value is greater than the Critical Value.

Based on Table 4, it can be seen that there are five equations that have a trace statistic value greater than the critical value. This means that there are five equations that are cointegrated in the system, so it can be concluded that there is a relationship between long-term stability and long-term movement. Meanwhile, in the short-term, it tends to adjust to achieve long-term balance/stability.

Table 4. Cointegration Test Result

\begin{tabular}{|c|c|c|c|c|}
\hline $\begin{array}{l}\text { Hypothesized } \\
\text { No. of CE(s) }\end{array}$ & Eigenvalue & $\begin{array}{c}\text { Trace } \\
\text { Statistic }\end{array}$ & $\begin{array}{c}0.05 \\
\text { Critical Value } \\
\end{array}$ & Prob.** \\
\hline None * & 0.969062 & 388.3116 & 150.5585 & 0.0000 \\
\hline At most $1 *$ & 0.826598 & 228.4256 & 117.7082 & 0.0000 \\
\hline At most $2 *$ & 0.677329 & 147.8271 & 88.80380 & 0.0000 \\
\hline At most $3 *$ & 0.600326 & 95.79541 & 63.87610 & 0.0000 \\
\hline At most $4 *$ & 0.487497 & 53.60859 & 42.91525 & 0.0031 \\
\hline At most 5 & 0.352207 & 22.85995 & 25.87211 & 0.1133 \\
\hline At most 6 & 0.060842 & 2.887507 & 12.51798 & 0.8896 \\
\hline
\end{tabular}

*significant at the level of $5 \%$

\section{Granger Causality Test}

Based on the Granger causality test, if the probability value is less than 5 percent, it can be concluded that there is a causality relationship among the existing variables. (Basuki, 2018). Therefore, Granger causality test is conducted.

Table 5. Granger Causality Test Result

\begin{tabular}{ll}
\hline Null Hypothesis: & Prob. \\
\hline DPK does not Granger Cause PP & 0.2257 \\
PP does not Granger Cause DPK & 0.6691 \\
NPF does not Granger Cause PP & $0.011 *$ \\
PP does not Granger Cause NPF & 0.1952 \\
INF does not Granger Cause PP & 0.7257 \\
PP does not Granger Cause INF & 0.0994 \\
KURS does not Granger Cause PP & 0.2976 \\
PP does not Granger Cause KURS & 0.4679 \\
SBIS does not Granger Cause PP & 0.3080 \\
PP does not Granger Cause SBIS & 0.3271 \\
IPI does not Granger Cause PP & $0.0078^{*}$ \\
PP does not Granger Cause IPI & 0.1371 \\
\hline
\end{tabular}

*significant at the level of 5\%

Based on the results of Table 5, the NPF probability value is 0.0117 , so it is statistically significant to affect LNPP and the LNIPI probability value is 0.0078 , so it is statistically significant to affect LNPP. Therefore, it can be concluded that there is a one-way causal relationship between NPF and agricultural financing (LNPP), as well as between Industrial Production Index (IPI) and agricultural financing (LNPP). However, there is no reciprocal relationship in the opposite direction. 


\section{VECM Model Estimation}

Tabel 6. Estimation Result in the Long and Short Term

\begin{tabular}{lcc}
\hline \multicolumn{1}{c}{ Variables } & Coefficient & T-statistic \\
\hline Short-Term & & \\
D(LNPP(-1)) & 0.409229 & 1.486184 \\
D(LNDPK(-1))) & -0.232438 & -0.773735 \\
D(NPF(-1)) & 0.006555 & 0.159879 \\
D(INF(-1)) & -0.011532 & -0.450432 \\
D(LNKURS(-1))) & -0.037033 & -2.041136 \\
D(SBIS(-1)) & -0.048602 & -0.887327 \\
D(LNIPI(-1))) & 0.088693 & 0.299548 \\
CointEq1 & -0.245647 & -1.13157 \\
C & -0.001505 & -0.12605 \\
Long-Term & & \\
LNDPK(-1)) & -1.226695 & $-2.31794^{*}$ \\
NPF(-1) & -0.156035 & 1.70104 \\
INF(-1) & 0.016127 & 0.60036 \\
LNKURS(-1)) & -0.038664 & $-3.69668^{*}$ \\
SBIS(-1) & -0.112434 & -1.28081 \\
LNIPI(-1)) & 0.775733 & $4.97675^{*}$ \\
C & 12.75084 & \\
\hline
\end{tabular}

*significant at level of 5\%

Based on Table 6, estimation results can be obtained in the short and long term. In the short-term, the VECM estimation results show that there is an error correction of -0.245647 which is not statistically significant. Correction of errors means that the imbalance will be corrected by 0.245647 percent to return to its long-term balance in the following month.

In the short term, all variables do not significantly affect agricultural financing (LNPP). Meanwhile in the long term, the variables that significantly influence agricultural financing are deposit funds (LNDPK), Exchange Rates (LNKURS), and Industrial Production Index (LNIPI). Meanwhile, the variables that do not have a significant effect in the long run are Non-Performing Financing (NPF), Inflation, and Bank Indonesia Sharia Certificate (SBIS).

In the long-term, the amount of DPK has a significant and negative effect of 1.226695. When there is a decrease in DPK, it will reduce agricultural financing by 1.226695. This is because DPK is funds collected from Islamic Commercial Bank customers which are then distributed for agricultural financing.

Furthermore, the exchange rate (LNKURS) has a significant and negative effect in the long-term of 0.038664 . When the exchange rate decreases, it will reduce agricultural financing by 0.038664. This means that when there is an increase in the exchange rate against the dollar, the rupiah increases and the price becomes expensive so that it affects agricultural financing.

Then the Industrial Production Index (LNIPI) has a significant and positive effect on agricultural financing of 0.775733 . When the Industrial Production Index (LNIPI) increases, it will increase agricultural financing. This means that when the economy is in good condition, it will support Islamic Commercial Bank financing activities, including financing activities for the agricultural sector. Therefore, once IPI increases, the funds for agricultural financing will also increase.

\section{Impulse Response Function Analysis (IRF)}

The next step is to conduct an Impulse Response Function (IRF) analysis. IRF analysis is used to see how agricultural financing responds towards the shock of other variables. 


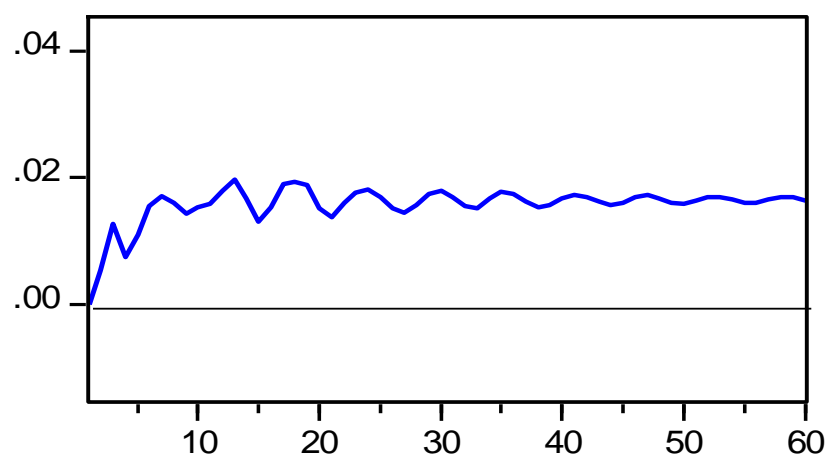

Figure 2. LNPP response towards the shock of LNDPK

Based on Figure 2, when there was a shock to the deposit funds (LNDPK), agricultural financing responded positively starting from the $2^{\text {nd }}$ month of 0.005316 and an increase until the $3^{\text {rd }}$ month of 0.012694 . Then it fluctuates from the $4^{\text {th }}$ month of 0.007481 to the $39^{\text {th }}$ month of 0.015660. The response started to reach a stability point at the $40^{\text {th }}$ month of 0.016769 . This condition is in accordance with the research of Veratama (2013) which stated that deposit funds have a significant effect on agricultural financing, meaning that deposit funds are the largest capital from Islamic Commercial Banks to channel financing so that it needs to be increased again in collecting funds from the public trust in this agricultural financing. This is also consistent with the theory stated that public funds collected and stored in banks are the largest source of funds that banks rely on. It consists of demand deposits, deposits and savings.

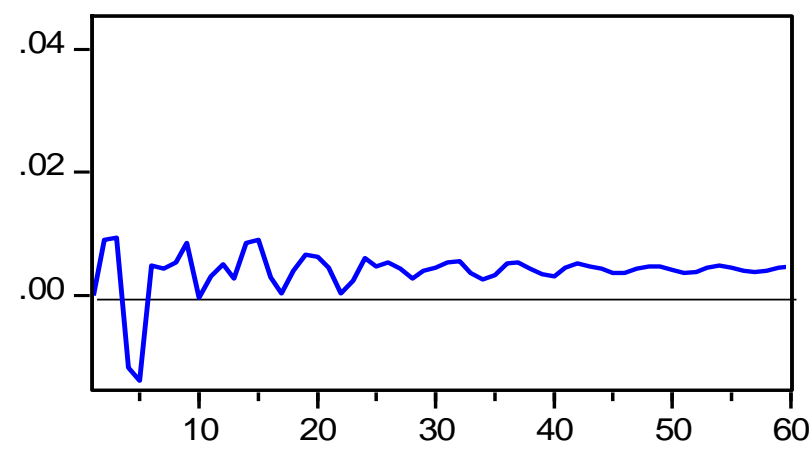

Figure 3. LNPP response towards the shock of NPF

Based on Figure 3, when a shock occurred in Non-Performing Financing (NPF), agricultural financing responded positively starting from the second month of 0.008940 and an increase until the $3^{\text {rd }}$ month of 0.009372 . Then began to respond negatively and reached the minimum point at the $4^{\text {th }}, 5^{\text {th }}$, and $10^{\text {th }}$ months. Then it started to be positive again and fluctuated from the $11^{\text {th }}$ month of 0.003050 to the $42^{\text {nd }}$ month of 0.005127 . The response started to reach a stability point on the $43^{\text {rd }}$ month of 0.004700 . The positive response from NPF shows that when an increase in NPF leads to an increase in financing, this is consistent with the research conducted by Mughits and Wulandari (2016) which stated that Islamic banking does not provide strict policies because Islamic Commercial Banks provide leniency in payments for financing from the public so that people can receive profit sharing in accordance with the distribution of funds to the agricultural sector in Indonesia. This condition is also in line with the theory that cost control has a relationship with the performance of banking institutions. The tighter the financing policies implemented by the Bank, the more pressure the NPF level will cause the level of demand for financing by the public to fall. 


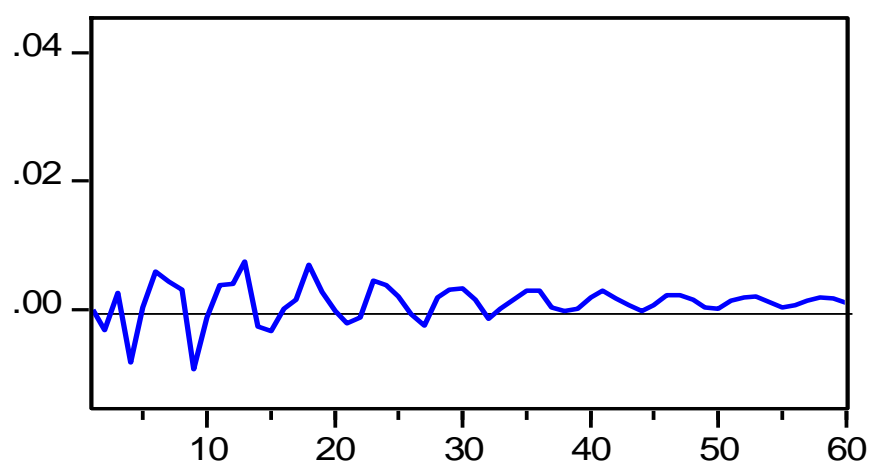

Figure 4. LNPP response towards the shock of INF

Based on Figure 4, when there was a shock to inflation (INF), agricultural financing responded negatively and reached the minimum point starting from the $2^{\text {nd }}$ month of -0.003266 and responded positively in the $3^{\text {td }}$ month of 0.002599 and again responded negatively in the $4^{\text {th }}$ month, responded positively again at the $5^{\text {th }}$ month to the $8^{\text {th }}$ month, again received a negative response at the $9^{\text {th }}$ month and $10^{\text {th }}$ month, again responded positively at the $11^{\text {th }}$ month to the $13^{\text {th }}$ month, again responded negatively at month $11-14$ and 15 months, responded positively again at the $16^{\text {th }}$ month to the $19^{\text {th }}$ month, again responded negatively at the $20^{\text {th }}$ month to the $22^{\text {nd }}$ month, again responded positively at the $23^{\text {rd }}$ month to the $25^{\text {th }}$ month, again responded negatively at the $26^{\text {th }}$ month and $27^{\text {th }}$ month, again responded positively at the $28^{\text {th }}$ month to the $31^{\text {st }}$ month, again responded negatively at the $32^{\text {nd }}$ month, again responded positively at the $33^{\text {rd }}$ month to the $37^{\text {th }}$ month, again responded negatively at $38^{\text {th }}$ month , again responded positively at the $39^{\text {th }}$ month to the $43^{\text {rd }}$ month, and then it responded negatively again at the $44^{\text {th }}$ month. It began to respond positively and reached a point of stability on the $45^{\text {th }}$ month of 0.000919 .

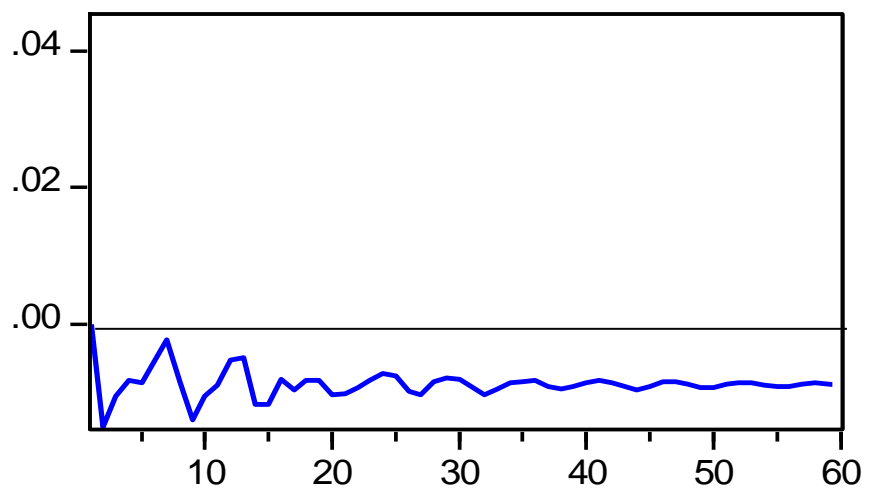

Figure 5. LNPP response towards the shock of LNKURS

Based on Figure 5, when there is a shock in the exchange rate (LNKURS), agricultural financing responds negatively and reaches a minimum point in the $2^{\text {nd }}$ month of -0.014990 until the $60^{\text {th }}$ month of -0.009036 . The negative response from agricultural financing shows that in the long run when the value of the rupiah against the dollar decreases or depreciates, then the financing channelled by Islamic Commercial Banks for the agricultural sector will decline. This means that when there is an increase in the rupiah exchange rate against the dollar, the foreign currency will increase while the value of the domestic currency depreciates so that the increase in the exchange rate can cause the price of raw materials to be more expensive and affect the distribution of agricultural financing. This is in accordance with the theory that the fluctuating impact of the exchange rate causes people to tend to want to have foreign currency so they withdraw funds from banks which results in banks experiencing difficulties in channelling their 
funds. This condition is in line with research from Mutamimah and Chasanah (2012) and Sarjadyasari (2013) which stated that changes in currency rates will also greatly affect the smooth running of customers' businesses. When the rupiah depreciates, it causes the prices of imported goods to be relatively expensive, so that financing for the agricultural sector can have an impact on the increase of NPF which can reduce agricultural financing.

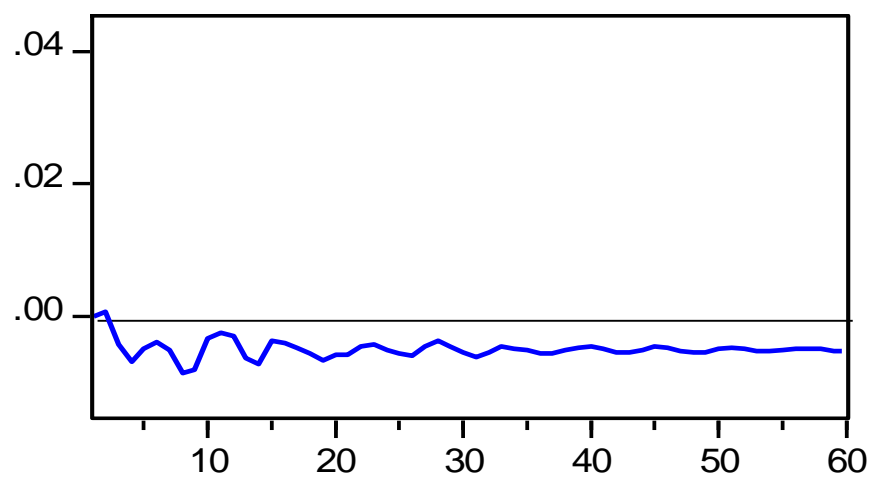

Figure 6. LNPP response towards the shock of SBIS

Based on Figure 6, when there was a shock to the Bank Indonesia Sharia Certificate (SBIS), agricultural financing responded positively in the $2^{\text {nd }}$ month of 0.000606 , then it was responded negatively and reached the minimum point in the $3^{\text {rd }}$ month of -0.004315 until the $2^{\text {nd }}$ month 60 in the amount of -0.005344 . This condition proves that the SBIS reward issued by Bank Indonesia has an effect on agricultural financing in the short-term and has no effect in the long-term. In accordance with the theory that SBIS is a short-term sharia-based securities in the rupiah currency issued by Bank Indonesia.

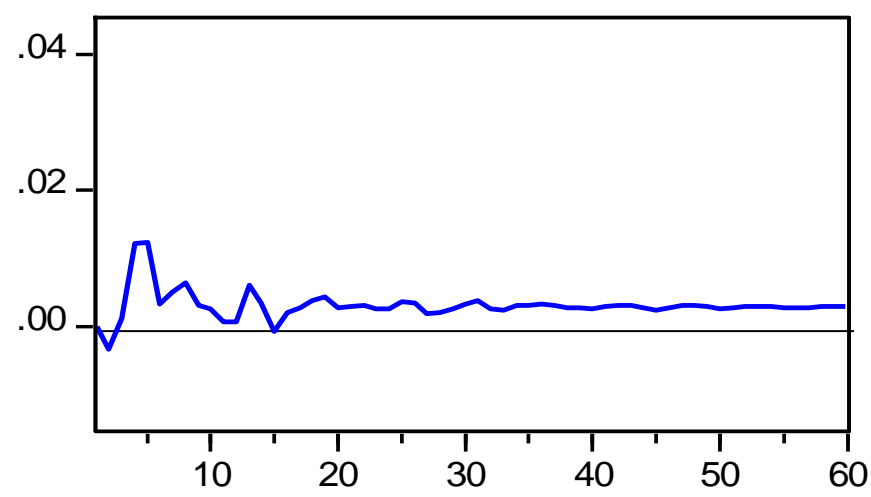

Figure 7. LNPP response towards the shock of LNIPI

Based on Figure 7, when there was a shock to the Industrial Production Index (LNIPI), agricultural financing responded negatively and reached the minimum point in the $2^{\text {nd }}$ month of 0.003312 , then responded positively in the $3^{\text {rd }}$ month by 0.001098 and in the 14 th month by 0.003395 . Further, it showed a negative response at the $15^{\text {th }}$ month by -0.000732 but then back to show ita positive response and reached a point of stability on the $16^{\text {th }}$ month by 0.002083 until the $60^{\text {th }}$ month by 0.002963 . This condition proves that the IPI variable affects agricultural financing in the long run. When the economy is in good condition, it will encourage Islamic Commercial Bank financing activities including financing activities for the agricultural sector. Therefore, once IPI has increased, the funds for agricultural financing will also increase. 
Based on all the results of the Impulse Response Function (IRF) analysis above as a whole, it shows that the response to agricultural financing that reaches a point of stability the fastest is when there is a shock from agricultural financing itself and deposit funds compared to other variables. This means that when experiencing shocks to DPK, agricultural financing will quickly stable.

\section{Forecasting Error Variance Decomposition (FEVD) Analysis}

Forecast Error Variance Decomposition is used to see how the contribution of other variables to agricultural financing. FEVD analysis shows how much the percentage contribution of each shock in the variables that affect agricultural financing at Islamic Commercial Banks in Indonesia. In this study, the time period used for FEVD analysis was 5 years consisting of 60 months.

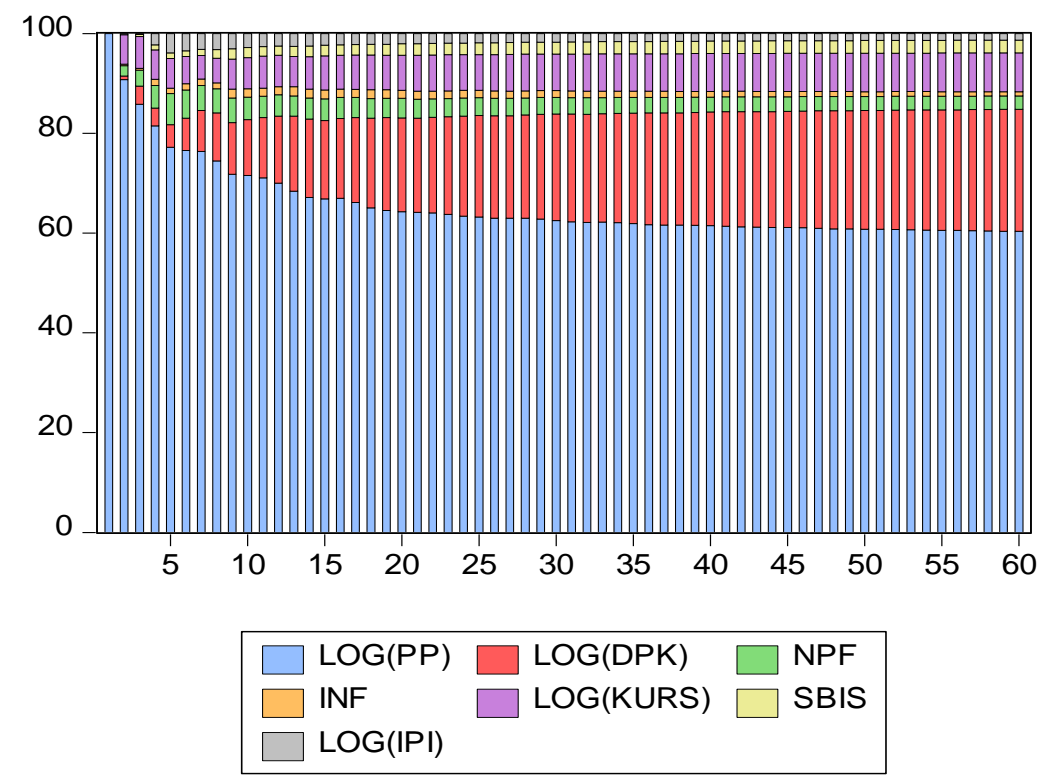

Figure 8. Variance Decomposition (\%) of Agricultural Financing (LNPP) Test Result

Based on Figure 81, it illustrates the FEVD results that give value to agricultural financing fluctuations. In the first month, agricultural financing fluctuations were dominated by agricultural financing itself by 100 percent, and continued until the final period with a decreasing value.

Furthermore, other variables began to have an effect on agricultural financing starting from the second month with the percentage for agricultural financing itself of 90.73 percent LNDPK of 0.73 percent, NPF of 2.08 percent, INF by 0.27 percent, LNKURS of 5.86 percent, SBIS of 0.009 percent, and LNIPI of 0,28 percent.

Further, at the $60^{\text {th }}$ month the contribution of each variable changes in value to agricultural financing. The contribution of agricultural financing to financing itself has decreased to 60.33 percent, DPK has increased to 24.46 percent, NPF has increased to 2.66 percent, inflation has increased to 0.85 percent, KURS has increased to 7.77 percent, SBIS has increased to 2.56 percent, and IPI increased to 1.32 percent.

Based on the results of the FEVD in Figure 8, it shows that the variable that most influences agricultural financing is deposit funds. The variable that has the greatest influence is deposit funds and the positive value is the funds collected from customers of Islamic Commercial Banks. This means that Islamic Commercial Banks must further improve in collecting funds from deposit funds to be channeled into financing for the agricultural sector, not only achieving a balance in the real sector, finance and other sectors.

Furthermore, the exchange rate variable has a positive effect on agricultural financing, but the percentage is smaller than the percentage of DPK. These results indicate that an increase in 
the exchange rate as a macroeconomic indicator has a long-term contribution to increase agricultural financing. The increasing value of the rupiah against the dollar (appreciated) will increase Islamic Commercial Bank financing for the agricultural sector in Indonesia, because the agricultural sector is one of the sectors that contributes to Indonesia's GDP and is able to increase the real sector. In addition to that, industrial production index (IPI) has a positive effect on agricultural financing, but is smaller than the exchange rate and SBIS. These results show that IPI as a macroeconomic indicator has an effect on agricultural financing, but the percentage is smaller on the increase in agricultural financing. This shows that an increase in production will increase agricultural financing.

\section{Conclusion}

Based on the results of the Granger causality, it shows that the NPF and Industrial Production Index (IPI) significantly affect agricultural financing (PP). Then the VECM estimation results show that in the short run all variables do not significantly affect agricultural financing (PP). Furthermore, in the long run, the variables of deposit funds (LNDPK), exchange rates (LNKURS), and industrial production index (LNIPI) significantly affect agricultural financing (PP). DPK and exchange rate have a negative effect, while IPI has a positive effect on agricultural financing. Hence, the variables that do not have a significant effect in the long run are NonPerforming Financing (NPF), Inflation, and Bank Indonesia Sharia Certificate (SBIS).

The results of the IRF show that the response to agricultural financing that reaches a point of stability the fastest is when there is a shock from the agricultural financing itself and deposit funds compared to other variables. Meanwhile, the FEVD results show that the variables that provide the greatest contribution to agricultural financing are agricultural financing itself and deposit funds compared to other variables.

This research only focuses on Islamic Commercial Banks, so it is suggested for further research to add Islamic Business Units (UUS) and Islamic Rural Banks (BPRS) as a comparison. In addition to that, it would also add the variables of Islamic banks' performance, monetary instruments, and different macroeconomic indicators.

\section{Acknowledgement}

Researchers would like to thank Associate Professor Heri Sudarsono for guiding this research until completion. Supervisor's suggestions are very useful, but not all suggestions can be included in this paper.

\section{References}

Ashari. (2009). Peran perbankan nasional dalam pembiayaan sektor pertanian roles of national banking in agricultural finance in Indonesia. Forum Penelitian Agro Ekonomi, 27(1), 13-27. http://dx.doi.org/10.21082/fae.v27n1.2009.13-27

Ashari, N., \& Saptana, N. (2016). Prospek pembiayaan syariah untuk sektor pertanian. Forum Penelitian Agro Ekonomi, 23(2), 132. https://doi.org/10.21082/fae.v23n2.2005.132-147

Basuki, A. T. (2018). Aplikasi model VAR dan VECM dalam ekonomi. Fakultas Ekonomi Univ. Mubammadiyah Yogyakarta, 1, 1-41. Retrieved from https://ekonometrikblog.files.wordpress.com/2018/06/bahan-ajar-model-var1.pdf

Beik, I. S., \& Aprianti, W.N. (2013). Analisis faktor-faktor yang memperngaruhi pembiayaan bank Syariah untuk sektor pertanian di Indonesia. Jurnal Agro Ekonomi, 31, 19-36. http://dx.doi.org/10.21082/jae.v31n1.2013.19-36

Jaya, Y. P., Rindayati, W., \& Ali, K. M. (2015). Analisis faktor-faktor penentu pembiayaan perbankan syariah pada sektor pengangkutan dan komunikasi di Indonesia. Al-Muzara'ah, 
3(1), 62-75. https://doi.org/10.29244/jam.3.1.62-75

Kusumawati, N. N. (2013). Analisis pembiayaan sektor konstruksi pada perbankan syariah di Indonesia Islamic banking financing analysis on construction sector in Indonesia. AlMuzara'ah, I(2), 191-203. https://doi.org/10.29244/jam.1.2.191-203

Majid, M. S. A., \& Ulina, S. (2020). Does the 2008-global financial crisis matter for the determinants of conventional and Islamic banking performances in Indonesia? Jurnal Ekonomi dan Keuangan Islam, 6(2), 77-90. https://doi.org/10.20885/jeki.vol6.iss2.art1

Masrizal, M., Miftahurrahman, M., Herianingrum, S., \& Firmansah, Y. (2020). The effect of country risk and macroeconomic on Jakarta Islamic Index. Jurnal Ekonomi dan Bisnis Islam, 6(1), 151. https://doi.org/10.20473/jebis.v6i1.14707

Maulana, H., \& Iskandar, E. (2018). Analisis integrasi pembiayaan sektor pertanian dan nilai tukar petani di Indonesia. Jurnal Ekonomi Regional Unimal, 01(3), 38-49. https://doi.org/10.29103/jeru.v1i3.1075

Mughits, M., \& Wulandari, R. (2016). Kontribusi pembiayaan bank syariah untuk sektor pertanian di Indonesia. Al-Muzara'ah, 4(1), 61. https://doi.org/10.29244/jam.4.1.61-75

Muhammad. (2005). Manajemen Pembiayaan Bank Syariah (2nd ed.). UPP STIM YKPN.

Nasution, Z. (2016). Model pembiayaan syariah untuk sektor pertanian. Iqtishadia: Jurnal Ekonomi \& Perbankan Syariah, 3(2), 324. https://doi.org/10.19105/iqtishadia.v3i2.1081

Permataningayu, G., \& Mahdaria, S. (2020). The effect of non-performing financing and financing to deposit ratio on Islamic banks financing in Indonesia. Asian Journal of Islamic Management, 1(1), 28-37. https://doi.org/10.20885/ajim.vol1.iss1.art3

Purwanto, P. (2018). Kontribusi pembiayaan sektor pertanian bank syariah terhadap kesejahteraan petani di pulau Sumatera periode 2016-2017. Share: Jurnal Ekonomi dan Keuangan Islam, 7(1), 37-58. https://doi.org/10.22373/share.v7i1.1646

Rahmah, A. Z., \& Armina, S. H. (2020). Macro and micro determinants of the non-performing finance: The case of Indonesian Islamic bank. Jurnal Ekonomi dan Keuangan Islam, 6(1), 3441. https://doi.org/10.20885/jeki.vol6.iss1.art4

Rahman, T., \& Fatmawati, K. (2020). The influence of financial ratios on non performing financing of the sharia rural banks of Special Region of Yogyakarta (BPRS DIY) period 2015-2018. Asian Journal of Islamic Management, 2(1), 25-35. https://doi.org/10.20885/ajim.vol2.iss1.art3

Saragih, F. H. (2017). Pembiayaan syariah sektor pertanian. Jurnal Agrica, 10(2), 112. https://doi.org/10.31289/agrica.v10i2.1458

Septindo, D., Novianti, T., \& Lubis, D. (2016). Analisis pengaruh instrumen moneter syariah dan konvensional terhadap penyaluran dana ke sektor pertanian di Indonesia. Al-Muzara'ah . 4(1), 1-18. https://doi.org/10.29244/jam.4.1.1-18

Sudarsono, H. (2017). Modelling respon rasio keuangan terhadap pembiayaan pada bank Syariah di Indonesia. Jumal Ekonomi Syariah Indonesia), 7(1), 1-13. https://doi.org/10.21927/jesi.2017.7(1).1-13

Sudarsono, H., Mifrahi, M., Susantun, I., Rudatin, A., \& Ruchba, S. (2020). Analysis of factor affecting financing with Islamic banks in agriculture sectors. Asian Journal of Islamic Management, 1(2), 116-126. https://doi.org/10.20885/ajim.vol1.iss2.art6

Suseno, \& Astiyah, S. (2010). Inflasi, Seri Kebanksentralan No. 22, Bank Indonesia, 1-57. Retrieved from https://ipief.umy.ac.id/wp-content/uploads/2020/02/22.-Inflasi.pdf 
Suseno, \& Simorangkir, I. (2004). Sistem dan kebijakan nilai tukar. Pusat Pendidikan dan Studi Kebanksentralan (PPSK) BI, 12(12), 61. https://www.bi.go.id/id/publikasi/serikebanksentralan/Documents/12. Sistem dan Nilai kebijakan Nilai Tukar.pdf

Syafi'i, A, M. (2001). Bank Syariab $\square$ : dari teori ke praktek. Jakarta $\square$ : Gema Insani Press.

Syahri, N., \& Harjito, D. (2020). The effect of financing using the principle of profit-loss sharing on profitability level of commercial Islamic bank registered in Bank Indonesia. Asian Journal of Islamic Management, 2(1), 46-58. doi:https://doi.org/10.20885/ajim.vol2.iss1.art5

Tsabita, K. (2014). Analisis risiko pembiayaan syariah pada sektor pertanian. Al-Muzara'ah, 2(2), 88-120. https://doi.org/10.29244/jam.2.2.88-120

Veratama, Y. (2013). Pengaruh kurs, inflasi, DPK, SWBI, dan pendapatan bank terhadap tingkat pengguliran dana bank syariah. 1-17. Retrived from http://eprints.dinus.ac.id/8862/1/jurnal_13819.pdf 